ТЕОРІЯ ТА ІСТОРІЯ ДЕРЖАВИ І ПРАВА;

ІСТОРІЯ ПОЛІТИЧНИХ І ПРАВОВИХ УЧЕНЬ

УДК $340 ; 342.7$

DOI https://doi.org/10.32844/2618-1258.2019.6.1

КРУГОВА С.С.

\title{
РЕТРОСПЕКТИВА СТАНОВЛЕННЯ РІВНОСТІ ПРАВ І СВОБОД ЖІНОК ТА ЧОЛОВІКІВ У СВІТІ ТА НА ТЕРИТОРІЇ УКРАЇНИ
}

У статті проаналізовано специфіку генезису становлення рівності прав і свобод жінок та чоловіків у світі. Визначено авторську етапізацію досліджуваної проблематики. Охарактеризовано особливості кожного з періодів. Також розкрито зміст становлення рівності прав і свобод жінок та чоловіків на території України. Наведено періодизацію вказаного напряму дослідження. 3'ясовано, що значення ідей гендерної рівності в епоху Відродження полягає передусім у тому, що вони зародились, жили та розвивались і надалі, внаслідок чого знайшли відгук у наступних поколіннях європейської інтелігенції. Як наслідок цього вже наприкінці XVIII століття розпочався процес закріплення прав жінок у законодавстві. По суті, iз настанням ери прав людини розпочалась і ера зрівнювання жінок у правах із чоловіками, яка триває і донині. Визначено, що на українських землях, на відміну від Західної Свропи, жінки наділялись широким обсягом прав та свобод ще в IX-XIV столітті. Звичайно, при цьому варто враховувати, що йдеться про права жінок серед вільних підданих Київської Русі, адже за наявності елементів патріархального рабства холопи не були суб'єктами правових відносин. На цей час розвиток рівності прав чоловіків та жінок в Україні полягає передусім в поширенні цього принципу на окремі сфери. Зроблено висновок, що рівноправність жінок та чоловіків $\epsilon$ історично притаманною для українського народу. Навіть у ті часи, коли в розвинених державах світу жінки були фактично позбавлені будь-яких прав, на українських землях жінки брали участь в управлінні державою, могли володіти майном, наділялись рядом прав у сімейних правовідносинах тощо. Після входження українських земель до складу Російської імперії та Австро-Угорської імперії, під впливом законодавства цих держав та релігійних канонів рівноправ'я було втрачене. Однак соціалістичний режим знову повернув права жінкам, які за часів незалежності України лише розширились і зараз фактично $є$ такими самими, як і у чоловіків. У дослідженні продемонстровано, що гендерна рівність $€$ історичною особливістю українського народу. Саме тому важливо, щоб в сучасних умовах це досягнення не було втрачене.

Ключові слова: рівність прав і свобод, права жінок, права чоловіків, ретроспектива, гендерна рівність.

In the article the specifics of the genesis of the formation of equality of rights and freedoms of women and men in the world are analyzed. The author's staging of the researched problems is determined. The peculiarities of each of the periods are described. The content of the formation of equality of rights and freedoms of women and men on the territory of Ukraine is also revealed. The periodization of the specified direction of research is given. It was found that the significance of the ideas of gender equality in the

(C) КРУГОВА С.С. - аспірантка (Інститут держави і права імені В.М. Корецького Національної академії наук України) 
Renaissance lies primarily in the fact that they originated, lived and developed further,
as a result of which they found a response in the next generations of the European intel-
ligentsia. As a result, the process of enshrining women's rights in law began at the end of
the 18th century. In fact, with the advent of the human rights era, the era of equalization
of women's rights with men began, which continues to this day. It is determined that in
the Ukrainian lands, in contrast to Western Europe, women were endowed with a wide
range of rights and freedoms in the IX-XIV centuries. Of course, it should be borne in
mind that we are talking about the rights of women among the free subjects of Kievan
Rus, because in the presence of elements of patriarchal slavery, slaves were not subjects
of legal relations. Today, the development of equality of rights of men and women in
Ukraine is primarily the extension of this principle to certain areas. It is concluded that
equality of women and men is historically inherent in the Ukrainian people. Even at a
time when women in the developed world were virtually deprived of any rights, in the
Ukrainian lands women participated in governing the state, could own property, were
given a number of rights in family relationships, and so on. After the Ukrainian lands
became part of the Russian Empire and the Austro-Hungarian Empire, under the influ-
ence of the legislation of these states and religious canons, equality was lost. However,
the socialist regime has restored the rights of women, which have only expanded since
Ukraine's independence, and are now virtually the same as men. The study demonstrates
that gender equality is a historical feature of the Ukrainian people. That is why it is im-
portant that in modern conditions this achievement is not lost.

Key words: equality of rights and freedoms, women's rights, men's rights, retrospective, gender equality.

Вступ. Побудова в Україні демократичної, соціальної і правової держави потребує забезпечення прав і свобод громадян. Це свідчить про важливість пошуку коректних співвідношень у зв'язку суспільства, держави і прав людини. Одним із першочергових напрямів вирішення цієї задачі є врегулювання питання рівності прав і свобод жінок та чоловіків, адже, як свідчить досвід усіх розвинених держав світу, основні права й обов'язки жінок, які визначають їх становище у суспільстві, міру юридичної свободи та відповідальності, створюють необхідні умови для всебічного розвитку особи, задоволення ії інтересів та потреб, мають відповідати аналогічним основним правам чоловіків.

Становище жінки в Україні та в світі порівняно із чоловіками все ще залишається складним. Залишаються проблемними питання рівня оплати праці та попиту на робочу силу тощо у тих галузях промисловості, де традиційно переважають жінки. Дотепер актуальними залишаються гендерні стереотипи щодо переважного зайняття жінкою господарськими справами сім'ї та вихованням дітей. Як наслідок, це позначається на просуванні жінок по службі, зменшенні їх конкурентоспроможності на ринку праці, адже поки жінки займаються вихованням дітей, чоловіки самоудосконалюються та зростають як фахівці. Незважаючи на очевидні фізіологічні відмінності чоловіків та жінок, різниця у становищі між обома статями є більшою мірою стереотипною, що негативно позначається на можливостях самореалізації жінки у суспільстві. Саме тому для нашого дослідження важливим питанням $є$ встановлення ретроспективи становлення рівності прав і свобод жінок та чоловіків у світі та на території України, адже лише повне розуміння усіх світових процесів, пов'язаних із гендерною рівністю, дозволить забезпечити відповідну рівність прав і в Україні.

Стан дослідження. Тією чи іншою мірою це питання розглядалось більшістю дослідників гендерної рівності. Відзначимо внесок у розробку наукової теорії гендерної рівності таких вчених, як І.П. Андрусяк, Н.Б. Болотіна, Н.О. Бондаренко, І.М. Грабовська, Н.В. Грицяк, О.Р. Дашковська, Т.Р. Деметрадзе, Т.Ю. Журженко, В.І. Івченко, А.І. Кормич, Т.М. Краснопольська, Н.В. Лавриненко, К.Б. Левченко, О.В. Литвинчук, Т.О. Марценюк, Т.М. Мельник, О.А. Мірошніченко, С.М. Оксамитна, Т.В. Омельченко, Н.М. Оніщенко, О.М. Рудік, О.М. Руднєва, С.М. Сєргєєва, Т.І. Фулей, В.В. Черняхівська та інших дослідників. Більшість таких праць не мають комплексний характер і присвячені лише окремим аспектам становлення прав і свобод жінок та чоловіків у світі та на території України, наприклад, прийняттю тих чи інших нормативно-правових актів. Також наявні праці, присвячені розвитку гендерної рівності в Україні, або у світі. Разом із тим комплексних досліджень, присвячених одночасно світовим та національним процесам, сьогодні фактично немає. 
Постановка завдання. Метою статті є дослідження ретроспективи становлення рівності прав і свобод жінок та чоловіків у світі та на території України.

Результати дослідження. Дуже довгий час проблеми рівності прав жінок та чоловіків взагалі не розглядались на науковому рівні. Так, С.М. Сєргєєва вказує на те, що не можна встановити якусь конкретну дату, із якої розпочався розвиток рівноправ'я чоловіків та жінок у світі [1, с. 284]. Неоднозначне ставлення до прав та свобод жінки було зафіксоване ще у працях давньогрецьких вчених. Так, Н.О. Бондаренко посилається на праці різних мислителів, сутність думок кожного із яких дійсно відрізняється суттєвим чином. Так, Сократ стверджував, що трьома речами, які можна вважати щастям, $\epsilon$ те, що ти людина, а не дика тварина; що ти грек, а не варвар; що ти чоловік, а не жінка [2, с. 88]. Так само Арістотель вважав жінок меш розвиненими, ніж чоловіків, а тому мислитель наголошував на тому, що відносини в сім’ї мають будуватись на основі панування чоловіка над жінкою. При цьому дослідник підкреслював, що жінка не є рабом чоловіка і займає суспільне становище вище від рабів, адже жінки, на його думку, є здатними до прийняття суспільно-політичних рішень [2, с. 88]. Про спірність таких підходів, навіть абстрагуючись від сучасних поглядів, свідчить те, що сучасники цих мислителів розглядали гендерне питання інакше. Так, Платон у праці «Держава» розвивав ідею про рівноправність чоловіків і жінок: «Однакові природні властивості зустрічаються у живих істот тієї й іншої статі і за своєю природою як жінки, так і чоловіка можуть брати участь в усіх справах» [2, с. 88]. Проте одразу варто відзначити, що таку рівноправність Платон розглядав лише у контексті правителів та стражів, а простого населення ці погляди не стосувались. У рівноправність статей Платон вкладав рівне виховання жінок із чоловіками, навчання їх військовій справі. Разом із тим окремі сфери, згідно поглядів Платона, мали бути повністю розділеними між чоловіками та жінками. Наприклад, винятково жінки мали б займатись вихованням малолітніх, наглядом за шлюбами та навчанням молоді. Своєю чергою чоловіки мали займатись державними справами [2, с. 88]. Отже, незважаючи на те, що Платон все ж розділяв чоловіків та жінок і надав останнім менший обсяг прав, очевидно, що цей мислитель цінував здібності жінок і звертав увагу на необхідність наділення їх відповідним становищем у суспільстві. позиції:

Таким чином, серед античних мислителів-класиків домінували дві, по суті, протилежних танніх;

1) жінки відрізняються від чоловіків і мають перебувати у залежному становищі від ос-

2) жінки наділені природою такими самими здібностями, як і чоловіки, але сфери їх діяльності все таки варто розділяти.

Обидва підходи $є$ тотожними за своїм змістом у тій частині, що усіма мислителями визнавалась необхідність розрізняти права чоловіків і жінок. 3 іншого боку, їх внесок у розвиток гендерної рівності полягає у тому, що вони першими підняли питання рівності жінки і чоловіка та висловили думки про можливість участі жінок у громадському житті.

Також внесок зазначених дослідників посилюється тим, що довгий період після цього ідеї рівності прав і свобод жінок та чоловіків не піднімались взагалі. Як зазначається у науковій літературі, до XX століття майже у всіх країнах світу у законах було закріплено підпорядкування жінок чоловікам. Чоловік мав панівне становище в сім'ї, майнові права також належали чоловікові, батьки вирішували, з ким візьме шлюб їхня донька. Своєю чергою жінки не мали права на фінансову незалежність, не розпоряджалися власністю, не отримували без дозволу чоловіка паспорт, не вибирали місце проживання. Законодавство багатьох європейських країн передбачало обов'язковий офіційний дозвіл чоловіка на працевлаштування його дружини [3, с. 106]. На становище жінок у суспільстві навіть не вплинули суттєво революції кінця XVIII століття, які вплинули позитивно на закріплення в законодавствах держав основних прав та свобод людини. C.M. Сєргєєва та O.I. Семиколєнова звертають увагу на те, що зміни щодо забезпечення прав жінок почали відбуватися у правовій системі тогочасної Європи після Французької революції 1789 року. Так, у 1789 році Олімпія де Гуж виголосила ідею рівності у «Декларації прав жінки та громадянки». Ії̈ вислів «Якщо жінки мають право виходити на ешафот, то вони можуть виходити й на трибуну» став гаслом для багатьох жінок світу. Величезним досягненням Французької революції став Декрет 1792 року про дієздатність жінок, які досягли 21 року. Узаконення розлучень у Франції, а потім і в інших країнах, підірвало підмурки сімейного деспотизму чоловіків [1, с. 284; 3, с. 106]. Схожі ідеї поширювались і в Англії. Наприклад, Марія Вольстонкрафт у своїй праці «На захист прав жінок» у 1792 році докладно описала становище неуцтва і рабської покірності, на яке через соціальні забобони і систему виховання були приречені жінки. Вчена проаналізува- 
ла «гідності жіночого характеру», підкресливши, що вони є результатом чоловічого погляду на жінок; критикувала погляди, які полягали у тому, що жінкою треба керувати; критикувала законодавство, яке закріплювало підлегле становище жінок [2, с. 90-91]. Не зважаючи на те, що ідеї рівності жінок та чоловіків отримали своє законодавче закріплення лише наприкінці XVIII століття, варто звернути увагу на те, що така концепція на той момент вже декілька століть розглядалась у тогочасному суспільстві. Так, ще в епоху Відродження в Свропі відбулись революційні зміни в культурному обличчі і в суспільній свідомості. У той період розпочалось формування однакового ставлення до чоловіків та жінок, що стало об'єктивною передумовою для виникнення ідеї жіночої рівноправності. Жінки почали залучатись до обговорення наукових і літературних тем, до жінки, iї розуму і духовного світу проявлялась повага у різноманітних творах. Мале коло освічених жінок зумовило виникнення руху за жіночу освіту. Разом із тим ідеї рівноправності мали занадто абстрактний характер і були далекими до втілення навіть серед знаті і коронованих персон [2, с. 89]. Значення ідей гендерної рівності в епоху Відродження полягає передусім у тому, що вони зародились, жили та розвивались і надалі, внаслідок чого знайшли відгук у наступних поколіннях європейської інтелігенції. Як наслідок цього, вже наприкінці XVIII століття розпочався процес закріплення прав жінок у законодавстві. По суті, із настанням ери прав людини розпочалась і ера зрівнювання жінок у правах із чоловіками, яка триває і донині.

Окрім Франції, в зазначений період відбувалась зміна поглядів щодо цього питання й у інших державах. Наприкінці XIX - на початку XX століття у законодавство низки держав під впливом масових жіночих рухів починали додаватись норми, які приділяти увагу захисту прав жінок. Переважно країни переглядали норми законодавства, особливо ті, що стосувались економічної сфери, оскільки все більше жінок були задіяні у промисловості, працюючи по 14 годин на заводах і фабриках [3, с. 106]. Жінки поступово залучались до промислового виробництва та були одним із об'єктів революцій культурних. Як наслідок відбувалось розширення їх соціально-економічних прав, а також почав змінюватись сам підхід ідей про становище жінки у суспільстві. Це дозволило жінкам із часом розраховувати на соціальний статус, загалом співставний в основних параметрах із чоловічим. Вони отримали рівні права у спадкуванні майна, право на розлучення, а також на обмеження батьківської влади над неповнолітніми дітьми.

При цьому звернемо увагу на те, що відповідні зміни вносились не лише країнами Європи, а й іншими державами світу. Наприклад, у 1893 році жінки здобули громадянські права у Новій Зеландії. В 1902 році аналогічні процеси відбулись в Австралії. Серед європейських держав одними із перших розширили права жінок Фінляндія у 1906 році, Норвегія в 1913 році та Данія. Все більша кількість країн змінювала своє законодавство і надавали жінкам додаткові права. Прикладом таких прав є виборчі права, яких раніше у жінок не було взагалі. Також права жінок отримали своє закріплення на рівні міжнародних угод. У 1902 році в Гаазі було прийнято конвенції, що врегулювали питання колізій у національних законодавствах щодо шлюбу, розлучення та опіки над неповнолітніми. Більшою мірою такі законодавчі нововведення були спрямовані проти торгівлі жінками: Договір про боротьбу з торгівлею білими рабинями 1904 року, Конвенція про боротьбу з торгівлею білими рабинями 1910 року та Женевська конвенція про заборону торгівлі жінками і дітьми 1921 року $[1$, с. 284]. Остаточно ідея наявності у жінки основних прав та свобод закріпилась у суспільстві після закінчення першої світової війни, у якій жінки взяли активну участь.

Таким чином, на світовому рівні ідея рівноправності жінок та чоловіків почала формуватися у період з кінця XVIII - початок XX століття. Виділимо такі особливості цього періоду у контексті становлення рівності прав і свобод жінок та чоловіків:

1) права жінок були розширені, особливо у частині соціально-економічних, політичних, спадкових та сімейних прав;

2) права жінок отримали своє нормативне закріплення, причому як на національних рівнях, так і на міжнародно-правовому;

3) змінився сам підхід до розуміння ролі жінок у суспільстві (зокрема, розпочалась боротьба із жіночим рабством);

4) фактично у цей період рівноправ'я встановлювалось за наступними напрямами: боротьба із злочинністю, спрямованою проти жінок; удосконалення національних законодавств в частині розширення прав жінок; залучення жінок до праці та виборів; розширення прав жінок як члена сім'ї.

Наступний етап становлення рівності прав і свобод жінок розпочався після другої світової війни. На науковому рівні цей період у розумінні розвитку ідей рівноправ'я розглядається у двох 
аспектах: у контексті прийняття найважливіших міжнародних законів, що розпочали епоху захисту прав жінок, та у контексті формування ідейних концепцій щодо прав жінок та їх місця в суспільстві.

У 1945 році було створено Організацію Об’єднаних Націй, до статуту якої були включені положення щодо недопущення будь-яких дискримінацій. У тому числі положення цього нормативно-правового акту містять формулювання щодо рівноправ'я чоловіків та жінок [4]. Один із перших кроків ООН полягав у прийнятті Загальної декларації прав людини [5], у статті 2 якої було встановлено, що «Кожна людина повинна мати всі права і всі свободи, проголошені цією Декларацією, незалежно від раси, кольору шкіри, статі, мови, релігії, політичних або інших переконань, національного чи соціального походження, майнового, станового або іншого становища» [5]. Нормативно-правові акти Організації Об'єднаних Націй, а також акти Міжнародної організації праці, по суті, і формують сьогодні нормативно-правову основу забезпечення рівноправності чоловіків та жінок. Варто першочергово виділити такі нормативно-правові акти: Конвенцію МОП про рівне винагородження чоловіків і жінок за працю рівної цінності від 29.06.1951 року №100, Конвенцію ООН про політичні права жінок від 20.12.1952 року, Конвенцію МОП про охорону материнства (переглянуту в 1952 році) від 28.06.1952 року № 103, Конвенцію ООН про громадянство заміжньої жінки від 29.01.1957 року, Конвенцію МОП про дискримінацію в галузі праці та занять від 25.06.1958 року № 111, Конвенцію ООН про боротьбу 3 дискримінацією в галузі освіти від 14.12.1960 року, Конвенцію ООН про згоду на взяття шлюбу, шлюбний вік та реєстрацію шлюбу від 10.12.1962 року, Конвенцію ООН про ліквідацію всіх форм дискримінації щодо жінок від 18.12.1979 року, яка є ключовим нормативно-правовим актом з погляду захисту індивідуальних та колективних прав жінок.

Зазначені нормативно-правові акти суттєво розширили права жінок у політичній сфері, зокрема, було закріплено право жінок на участь у виборах, а також на набуття громадянства свого чоловіка. В соціально-економічній сфері жінки отримали право на рівну оплату праці із чоловіками за виконання аналогічної роботи, на особливі умови праці для матерів, а також на заборону дискримінації жінок під час реалізації ними права на працю. В галузі освіти було встановлено заборону будь-яких дискримінацій, у тому числі і за статевою ознакою. Тобто було закріплено рівне право чоловіків та жінок на здобуття освіти. Ще однією сферою, у якій відбулось розширення прав жінок, є сімейна сфера. Так, сьогодні шлюб може укладатись лише у разі взаємної згоди обох сторін, а отже, шлюб не може бути укладено у разі відсутності на те волі жінки. Також було прийнято міжнародне законодавство, спрямоване на боротьбу із дискримінаціями жінок.

Тобто на підставі усього вищезазначеного ми можемо зробити висновок, що у період з 50-х до 80-х років ХХ століття поступово відбувалось зрівнювання у правах чоловіків та жінок. Звернемо увагу на те, що попри те, що рівноправність чоловіків та жінок у досліджуваний період була встановлена фактично в усіх розвинених країнах, окремі держави довгий час не запроваджували відповідний принцип у національному законодавстві. Наприклад, лише у 1971 році після тривалих дискусій жінкам у Швейцарії було надано виборче право. Відповідно, аналогічні норми були прийняті в Ліхтенштейні лише в 1984 році [1, с. 285]. Порівняно із попередніми історичними епохами права жінок були суттєво розширеними. Трудові права жінок були зрівняні iз правами чоловіків. Так само у сімейних відносинах ролі чоловіка та жінки зрівнялись, і було остаточно закріплено виборче право жінок. При цьому розширення прав жінок не будо здійснене за рахунок звуження прав чоловіків. У чоловіків залишився, по суті, той самий обсяг прав, а жінки, відповідно, отримали ті права, які раніше належали винятково чоловікам.

Таким чином, зробимо висновок, що становлення рівності прав і свобод чоловіків та жінок на цьому етапі його розвитку (від моменту закінчення другої світової війни до 80-х років XX століття) характеризується такими особливостями:

1) у зазначений період було прийнято міжнародне законодавство, яке фактично урівняло у правах чоловіків та жінок;

2) було суттєво розширено соціально-економічні, політичні, освітні та сімейні права жінок;

3) виникли ідейно-політичні течії, які у тому числі мали на меті зрівнювання у правах чоловіків та жінок (лібералізм, фемінізм, соціалізм).

Сучасний етап становлення рівності прав і свобод жінок та чоловіків у світі характеризується прийняттям законодавства про гендерну рівність на національних рівнях. Так, у 90-х роках XX століття Швеція, Голландія, Ісландія, Норвегія, Фінляндія, Польща, Литва, Японія, Франція та багато інших країн світу прийняли такі національні закони [3, с. 109]. Не є винятком і Україна, у якій відповідне законодавство також було прийняте та приймається і до сьогодні саме у зазначе- 
ний період. Також відзначимо те, що у зазначений період після IV Всесвітньої конференції ООН у 1995 році зі становища жінок у термінологічний обіг увійшло поняття «гендер», «Гендерний» для віддзеркалення соціальної нерівності між чоловіком і жінкою [2, с. 94]. Для становлення рівності прав і свобод чоловіків та жінок це означало визнання факту об'єктивного існування двох різних статей як нерозривних частин людства, суспільства і сім'ї. I чоловіки, і жінки характеризуються індивідуальними фізіологічними можливостями, які потребують урахування під час правового регулювання їх статусу у суспільстві.

В Україні питання, пов'язані із рівністю прав і свобод жінок та чоловіків, довгий період не були актуальними взагалі. Так, у ранньофеодальний період Русі (кінець IX - початок XIV ст.) статус жінки в давньоруському праві був набагато вищим, ніж, наприклад, у римському чи давньогерманському, де жінка, дочка, дружина та мати завжди перебували під опікою чоловіка і були позбавлені правоздатності. Своєю чергою на Русі жінка в шлюбі зберігала за собою все своє майно, яке і після смерті чоловіка не включалося у спільну спадщину, а вдова ставала повноправною головою сім'ї. Жінки могли мати особисту власність незалежно від громади, володіли правом на придане та спадок. Ще в дохристиянський період у дружин було своє майно, а княгині та інші знатні жінки володіли великими статками, містами, селами. Наприклад, княгині Ользі належало власне місто. Нерідкісними були випадки, коли чоловіки майново залежали від дружин. У тогочасних нормативно-правових актах відсутні будь-які свідчення про те, що дружина у будьякий спосіб обмежувалась у власному праві розпоряджатися своїм майном, яке включалось у загальну сімейну власність, і у володінні якою дружина брала участь нарівні з чоловіком і дітьми [6, с. 135-136]. Таким чином, зробимо висновок про те, що на українських землях, на відміну від Західної Європи, жінки наділялись широким обсягом прав та свобод ще в IX-XIV столітті. Звичайно, при цьому варто враховувати, що йдеться про права жінок серед вільних підданих Київської Русі, адже за наявності елементів патріархального рабства холопи не були суб'єктами правових відносин.

На той час було прийнято не так багато нормативно-правових актів, тому проблематично однозначно встановити, чи були права жінок та чоловіків рівними. Як відзначає В.В. Черняхівська, окремі обмеження прав жінок мали місце лише шляхом застосування релігійних канонів. Зокрема, жінка мала зберігати цнотливість до шлюбу, а в шлюбі бути вірною чоловікові, а чоловікам дозволялися не тільки дошлюбна свобода, а вільні погляди на вірність дружині. Церковні твори і проповіді містили в собі твердження про неповноцінність жінки, що принижувало їі значення в сім’ї і закріплювало нерівноправність жінок. Дружині заборонялося давати поради чоловікові на людях, демонструвати своє уміння розумітися у справах сім'ї, господарстві, в державному житті [6, с. 137]. Але разом із тим у Київській Русі були відсутні обмеження, характерні для інших держав, у яких серйозно обмежувалась дієздатність жінок як у соціальній, так і в економічній сферах. У Європі, як нами встановлювалось раніше, жінки не могли брати участь в управлінні державою, у тому числі й шляхом виборів, та не могли претендувати на престижні професії. Дружини служили своїм чоловікам та своїй сім'ї. В той самий час в Київській Русі жінки володіли та розпоряджались майном, а також наголосимо на тому, що для історії даної держави характерне правління жінки - княгині Ольги. Інші жінки також могли брати участь в державному житті та займати державницькі посади.

Щодо іншої тогочасної могутньої держави на українських землях -Галицько-Волинського князівства, то статус жінок все ж характеризувався меншою кількістю прав та свобод. Домінуюча роль у суспільстві належала чоловіку, втім соціальний статус жінки все одно був високим, особливо порівнюючи із європейськими державами. Так само як і в Київській Русі, певний період державою керувала жінка - Анна, вдова князя Романа Мстиславича, мати Данила Галицького і Василька, оскільки іiі сини були малолітніми. Ольга, дружина князя Володимир-Волинського князівства Володимира Васильовича, також брала участь у державних справах [6, с. 137]. Це свідчить про те, що у Галицько-Волинському князівстві обсяг прав жінок був масштабним. Основна особливість полягала у тому, що жінка могла стати керівником держави. В інших тогочасних розвинених державах така можливість не існувала.

Отже, зробимо висновок, що в епоху середньовічної Русі (IX-XIV століття) рівність прав і свобод жінок та чоловіків на українських територіях характеризувалось такими особливостями:

1) в Київській Русі та певною мірою в Галицько-Волинському князівстві існувала гендерна рівність серед вільних підданих жінок;

2) жінки були рівними із чоловіками у сімейних відносинах, володіли майном, брали участь в управлінні державою, мали економічну самостійність; 
3) після впровадження християнства статус жінки дещо змінився під впливом релігійних канонів, причому у гірший бік.

Наступний етап історії України пов'язаний із розпадом Русі та переходом українських земель під владу Великого князівства Литовського та королівства Польського (XIV-XVI століття). Відмітимо, що більшістю подібних прогресивних прав, прирівнюваних до прав чоловіків, наділялись винятково жінки шляхетського походження. У цьому аспекті правове регулювання прав жінок в королівстві Польському є близьким до правового регулювання у Київській Русі.

Звертаючись до законодавства Великого князівства Литовського, у XVI столітті було проведено систематизацію, внаслідок чого у литовських статутах було закріплено права та обов'язки як чоловіків, так і жінок. Тобто права жінок в Великому князівстві Литовському також були закріплені та гарантовані на законодавчому рівні. Звернемо увагу на те, що у Статуті Великого князівства Литовського 1529 року на жінок-вдів покладалося виконання військових обов'язків з оборони держави нарівні з чоловіками. Жінки не воювали безпосередньо власними силами, але відправляли для участі у воєнних діях повністю споряджених людей, забезпечивши їх зброєю, кіньми, провіантом, грішми тощо [6, с. 139]. Це дозволяє зробити висновок, що жінки реально брали участь у державному управлінні в Великому князівстві Литовському.

Таким чином, зробимо висновок, що за часів Великого князівства Литовського та королівства Польського:

1) жінки були фактично зрівняні у правах із чоловіками, у тому числі брали участь у державному управлінні, могли володіти нерухомим майном, на жінок могли працювати кріпаки тощо;

2) жінки були наділені правом виходити заміж за власною ініціативою;

3) гендерна рівність, як і в Київській Русі, не поширювалась на кріпаків.

Наступний період, який варто розглянути, - гетьмансько-козацька доба. Для жінок вищих станів зберігались права, проаналізовані нами раніше: права купувати і продавати рухоме й нерухоме майно, укладати угоди, звертатися до суду з позовом, особисто брати участь в судових засіданнях; залишити дівоче після заміжжя тощо [6, с. 141-142]. Відзначимо, що навіть на той період такі права ще не були характерними для іноземних держав. Наприклад, у Запорозькій Січі могли проживати лише неодружені чоловіки або такі, які розірвали шлюб. Тому саме існування цієї держави не залишило жодного сліду для утвердження рівності прав жінок та чоловіків. А в деяких випадках права жінок навіть обмежувались, враховуючи те, що жінка не могла проживати на території Січі та навіть потрапити до неї [6, с. 142]. Разом із тим у Гетьманщині соціальний статус жінок старшинських, козацьких та міщанських родин був високим порівняно із Росією та країнами Західної Європи. Жінки з таких родин могли втручатись у політичні та військові справи, вели великі господарства, видавали офіційні універсали, накази та інструкції, тобто нормативно-правові акти, які мали юридичну силу в козацькій державі і були обов'язковими до виконання [6, с. 143]. При цьому такий їх статус був звичним для тогочасного суспільства і сприймався як належне. Тобто тоді як у всьому світі права жінок максимально обмежувались, на українських територіях рівність жінок та чоловіків існувала протягом декілька століть. I після підпорядкування Гетьманщини Російській імперії у другій половині XVIII століття настає період поступового обмеження й позбавлення українських жінок значної кількості суспільно-політичних прав. У результаті політична гендерна рівноправність в українському суспільстві зникла повністю.

Наступний етап ознаменував початок боротьби за права жінок на території Російської імперії, у тому числі і на українських землях. Це, зокрема, здійснювалось під впливом ідей Французької революції 1789 року та Просвітництва, а тому можна зробити висновок про те, що ці процеси на українських землях загалом співпали із аналогічними процесами в європейських державах. Як зазначає С.А. Петреченко, через Річ Посполиту, а згодом і Австрійську (а з 1867 року Австро-Угорську) імперію, в правову свідомість проникали європейські ідеї, в тому числі щодо захисту прав жінок [7, с. 128]. Так, в Австрійській імперії навіть жінки-аристократки були відсторонені від державного та самоврядного управління і не мали соціально-політичних прав, якими користувалися чоловіки [6, с. 148-149]. Землі, які опинилися в складі Російської імперії, розвивалися під впливом загальноімперського законодавства, але характерним для земель Лівобережжя було поширення місцевого звичаєвого права. Права жінок станом на XVIII століття вже суттєво обмежувались, порівняно з чоловіками, причому такі обмеження мали місце стосовно різноманітних видів прав: економічних, політичних, спадкових, сімейних, трудових тощо. Жінки не могли працювати на тих самих роботах, що й чоловіки. Під час розподілу майна в порядку спадкування жінкам діставалась менша частка порівняно із чоловіками. Жінки втратили право брати участь у виборах. I це лише неповний перелік прав, у яких жінки були обмежені. Вже ста- 
ном на XIX століття державно-правовий статус жінки на українських землях у складі Російської імперії практично не відрізнявся від загальноімперського і при цьому суттєво відрізнявся від державно-правового статусу чоловіків [7, с. 128].

Юридичне закріплення гендерної рівності в державному управлінні та фактична реалізація цього соціального явища розпочинається з революційних демократичних подій в Україні 1917-1918 pр. та створення основ української національної держави і права. Так, у статті 11 Розділу II «Права громадян України» Конституції Української Народної Республіки (Статуту про державний устрій, права і вільності УНР) від 29 квітня 1918 року було встановлено, що «Ніякої різниці в правах і обов'язках між чоловіком і жінкою право УНР не знає» [8]. На той момент таке конституційне положення не мала жодна країна світу. Із утворенням Західноукраїнської Народної Республіки наприкінці 1918 року схоже положення було закріплене і у Тимчасовому основному законі про державну самостійність українських земель колишньої австро-угорської монархії, ухваленому Українською Національною Радою на засіданні 13 листопада 1918 року [6, с. 152-153]. Разом із закріпленням цього положення жінки отримали і низку прав, зокрема, право на участь у виборах до парламенту, право на заняття владних та судових посад тощо.

Рівність прав чоловіків і жінок на території України набула остаточного закріплення із перемогою листопадової революції, а згодом з утворенням СРСР. Жінка почала сприйматись як учасник будівництва соціалістичного суспільства. Жінці було надано такі ж права, як і чоловікам. Жінка активно залучалась до ключових робіт, а їі права забезпечувались загальнодержавними гарантіями. Разом із тим питання прав жінок у СРСР було суспільно-політичним. Для партії було важливим використовувати жінку і як матір, і як рівного із чоловіками працівника. Жінка сприймалась як важливий фактор суспільних перетворень та соратник чоловіка в щоденній соціалістичній боротьбі. Тому вже в 1960 -х роках жінка нарівні з чоловіками працювала на виробництві [9, с. 120]. Відповідні положення щодо рівності прав та свобод чоловіків і жінок отримували закріплення у кожній із прийнятих Конституцій УСРР. Так, у Конституції 1919 року за жінками було закріплено право обирати та бути обраними [10]. Про рівність статей у відповідній нормі не йшлось, проте вона поширювалась на усіх без винятків громадян, а отже, і на жінок. Вже у статті 66 Конституції УСРР 1929 року було чітко зазначено, що «Право обирати і бути обраним до рад мають, незалежно від статі, віри, раси, національності, осілості тощо, такі громадяни Української Соціалістичної Радянської Республіки, що їм до дня виборів минуло 18 років» [11]. Тобто в цій нормі законодавець чітко вказав на те, що виборче право поширюється на громадян безвідносно до ознаки статі. В Конституції УРСР 1937 року права жінок були ще суттєвіше розширені. Жінці в СРСР згідно зі статтею 121 даного нормативно-правового акту було надано рівні права 3 чоловіком у всіх сферах господарського, державного, культурного та суспільно-політичного життя. Тобто жінок було наділено рівними із чоловіком правами на працю, оплату за працю, відпочинок, соціальне страхування та освіту, державну охорону інтересів матері та дитини, надання жінці при вагітності відпусток зі збереженням утримання тощо. Відзначимо, що на той момент така норма була прогресивною, адже жодна держава світу не закріплювала вичерпне коло рівних прав для чоловіків та жінок на конституційному рівні. В Конституції УРСР 1978 року [12] це положення було також закріплене.

Проголошення у 1991 році незалежності України створило умови для осмислення проблеми прав жінок на принципово новому, національному рівні, що стимулювало діяльність у даному напрямі як науковців, так і законодавця. Діяльність науковців у цьому напрямі вже досліджувалась нами раніше у цій роботі. Щодо законодавства, то перш за все варто відзначити прийняття в 1996 році Конституції України [13], адже цей нормативно-правовий акт беззаперечно визначив запровадження політики країни по захисту материнства та рівних прав жінки й чоловіка.

Сьогодні розвиток рівності прав чоловіків та жінок в Україні полягає передусім у поширенні цього принципу на окремі сфери. Наприклад, під час реформування поліції було здійснено спробу встановлення досконалішого гендерного балансу в оновленому складі. Також за останні роки було легалізовано службу жінок в армії, скасовано перелік заборонених для жінок професій, а також удосконалено законодавство про працю із метою боротьби з дискримінаціями. Усе вищезазначене свідчить про те, що керівництвом держави сьогодні докладаються зусилля для того, щоб остаточно побороти гендерну нерівність в Україні.

Висновки. Таким чином, у процесі дослідження нами встановлено, що рівноправність жінок та чоловіків $\epsilon$ історично притаманною для українського народу. Навіть у ті часи, коли в розвинених державах світу жінки були фактично позбавлені будь-яких прав, на українських землях жінки брали участь в управлінні державою, могли володіти майном, наділялись рядом прав у 
сімейних правовідносинах тощо. Після входження українських земель до складу Російської імперії та Австро-Угорської імперії під впливом законодавства цих держав та релігійних канонів рівноправ'я було втрачене. Однак соціалістичний режим знову повернув права жінкам, які за часів незалежності України лише розширились і сьогодні фактично $є$ такими самими, як і у чоловіків. Наше дослідження продемонструвало, що гендерна рівність $є$ історичною особливістю українського народу. Саме тому важливо, щоб у сучасних умовах дане досягнення не було втрачене.

\section{Список використаних джерел:}

1. Сергєєва С.М. Міжнародно-правовий захист прав жінок: історія і сучасність. Часопис Київського університету права: Украӥнський науково-теоретичний часопис. 07/2011. № 3. C. $284-288$.

2. Бондаренко Н.О. Історичні аспекти розвитку вчень про права жінок. Форум права. 2011. № 2. C. 87-96.

3. Семиколєнова О. «Ми різні - ми рівні». Основи культури гендерної рівності: Навчальний посібник для учнів 9-12 класів загальноосвітніх навчальних закладів. Київ : «К.І.С.», 2007. $176 \mathrm{c}$.

4. Статут Організації Об’єднаних Націй і Статут Міжнародного Суду ООН: Міжнародний документ від 26.06.1945. URL: https://zakon.rada.gov.ua/laws/show/995_010 (дата звернення: 20.04.2019).

5. Загальна декларація прав людини: Міжнародний документ від 10.12.1948. URL: https://zakon.rada.gov.ua/laws/show/995 015 (дата звернення: 20.04.2019).

6. Черняхівська В.В. Гендерна політика в системі державного управління: Україна та Свропейський досвід : дис. ... канд. наук з держ. упр. : 25.00.01 / В.В. Черняхівська ; Нац. акад. держ. упр. при Президентові України. Київ: [б. в.], 2017. 257 с.

7. Петреченко С.А. Розвиток інституту права власності на українських землях у складі Російської імперії наприкінці XVIII - на початку XIX ст. : дис. ... канд. юрид. наук : спец. 12.00.01 «Теорія та історія держави і права; історія політичних і правових учень». Київ, 2014. 196 с.

8. Конституція Української Народної Республіки (Статут про державний устрій, права i вільності УНP): Історичний документ. URL: https://zakon.rada.gov.ua/laws/show/n0002300-18 (дата звернення: 20.04.2019).

9. Петреченко С. Права жінок у XXI столітті: історико-правовий аспект. Вісник Львівського університету. Серія юридична. 2014. Вип. 60. С. 117-124.

10. Конституція Української Соціялістичної Радянської Республіки (березень 1919 р.): Історичний документ від 10.03.1919. URL: https://zakon.rada.gov.ua/laws/show/n0001316-19 (дата звернення: 20.04.2019).

11. Конституція Української Соціялістичної Радянської Республіки: Історичний документ від 23.06.1929 N 143. URL: http://gska2.rada.gov.ua/site/const/istoriya/1929.html (дата звернення: 20.04.2019).

12. Конституція (Основний Закон) України: Закон України від 20.04.1978 № 888-IX. URL: http:// https://zakon.rada.gov.ua/laws/show/888-09 (дата звернення: 20.04.2019).

13. Конституція України: Закон України від 28.06.1996 № 254к/96-ВР. Відомості Верховної Ради України. 1996. № 30. Ст. 141. 